BMJ Nutrition, Prevention \& Health

\section{Genetic factors associated with obesity risks in a Kazakhstani population}

To cite: Razbekova M, Issanov A, Chan M-Y, et al. Genetic factors associated with obesity risks in a Kazakhstani population. BMJ Nutrition, Prevention \& Health 2021;4:e000139. doi:10.1136/ bmjnph-2020-000139

${ }^{1}$ School of Medicine, Nazarbayev University, Nur-Sultan, Kazakhstan

${ }^{2}$ Eastern Health, Melbourne, Victoria, Australia

${ }^{3}$ National Laboratory Astana, Nur-Sultan (Astana), Kazakhstan

Correspondence to Dr Mei-Yen Chan, School of Medicine, Nazarbayev University, Nur-Sultan 010000, Kazakhstan; dryenchan@gmail.com

Received 14 July 2020 Revised 3 December 2020 Accepted 6 January 2021 Published Online First 5 February 2021
Check for updates

(C) Author(s) (or their employer(s)) 2021. Re-use permitted under CC BY-NC. No commercial re-use. See rights and permissions. Published by BMJ.

\author{
Madina Razbekova, ${ }_{1}^{1}$ Alpamys Issanov (D) , ${ }^{1}$ Mei-Yen Chan (D) , ${ }^{1}$ Robbie Chan, ${ }^{2}$ \\ Dauren Yerezhepov, ${ }^{3}$ Ulan Kozhamkulov, ${ }^{3}$ Ainur Akilzhanova, ${ }^{3}$ Chee-Kai Chan ${ }^{1}$
}


Meanwhile, both rs9939609 in FTO and rs4994 in adrenoceptor beta 3 (ADRB3) genes were statistically associated with obesity in Russians in Moscow and Sverdlovsk cities, Russia. ${ }^{15}$ Particularly, obese participants had significantly higher prevalence of $\mathrm{A} / \mathrm{A}$ or $\mathrm{A} / \mathrm{T}$ genotypes in rs9939609 of FTO gene than non-obese subjects. Prevalence of rs4994 in the adrenergic gene that has been linked to obesity and metabolic disorders were also statistically different among people with and without obesity. ${ }^{16}$ Furthermore, this SNP was reported to increase the risk of myocardial infarction, stroke and heart failure in predominantly Caucasian Americans. ${ }^{17}$ SNPs can exert different effects on people from various ethnic groups. For instance, obesity associated SNPs in NEGR1 and PRKD1 genes elicited heterogeneous effects on obesity risk in people with African and European descent. ${ }^{18} \mathrm{SNP}$ in GBE1 had different effects among Europeans and East-Asians. ${ }^{18}$ These findings suggest that a huge diversity of gene polymorphisms affect obesity risk differently in different populations. Therefore, in the Kazakhstani population, it would be useful to examine the impact of these SNPs on the risk of obesity and overweight of the different ethnic groups in the country, such as the Kazakhs and the Russians.

Currently, there is limited information focusing on the genetic determinants in various ethnic groups of Central Asia especially those on overweight/obesity and cardiovascular health. Further research in this area will help to elucidate the role of genes impacting cardiovascular health and their association with obesity. In this study, our aim was to investigate the association of various cardiovascular and endothelial health gene polymorphisms with overweight/obesity in the population living in Kazakhstan.

\section{MATERIALS AND METHODS}

\section{Data collection and study population}

Between June 2012 and May 2014 with the aim to study environmental, social and genetic factors determining susceptibility to tuberculosis and obesity in Kazakhstan, 1600 participants were recruited into the study. ${ }^{19} 20$ Participants were recruited from three regions namely Kyzylorda, Kostanay, Almaty oblast and Almaty city with the consideration to include sites in the northern and southern parts of the country, and the most densely populated regions. The informed consent forms were obtained by all participants, who then completed the questionnaire regarding their age, gender, socioeconomic status and habits-later regarded as potential confounders. Exposures were identified as SNPs, outcome-overweight or obesity.

\section{Genetic samples: purification and analysis}

Blood samples were collected from each participant using two vacutainer blood collection tubes (BD Vacutainer blood collection tubes) containing the anticoagulant (K2 EDTA) and polymer gel. The tubes were coded with an identifying number. Blood samples were centrifuged to separate plasma and serum, and the blood components were aliquoted into tubes and placed for $-800^{\circ} \mathrm{C}$ storage.

DNA was extracted from the blood samples using the Wizard Genomic DNA Purification Kit (Promega, Madison, Wisconsin, USA) according to the manufacturer's protocol. The purified DNA was quantitated, and quality ascertained using a NanoDrop spectrophotometer. For SNPs genotyping, an SNP array using quantitative real-time PCR on a Life Technologies Quantstudio 12K Real Time PCR system based on the cycle relative threshold method was employed. The results were entered and analysed with Life Technologies Copy Caller V.2.1 software. The reactions carried out were based on a two-step assay, each with two primers and a Taqman probe, one specific to the target of SNP. Overweight individuals were defined as those with BMI between 25 and 30 , while those with BMI higher than 30 were considered as obese according to WHO standards. ${ }^{1}$

\section{Statistical analysis}

The statistical analysis was performed using STATA V.12.0 software (StataCorp). Student's t-test and $\chi^{2}$ test were applied for bivariate analysis of data. Logistic regression was used to test whether the genotype and the allele in the SNPs were associated with OO. Factors such as age, sex, smoking status and ethnicity were measured for their possible confounding effects on the association between gene polymorphisms and $\mathrm{OO}$ in logistic regression. Stratification according to ethnicity (Kazakhs and Russians) was carried out to look at the effect of SNPs in each group. The statistically significant associations were reported according to $\alpha=0.05$ level. Bonferroni-corrected $\mathrm{p}$ values were calculated for pairwise comparisons.

\section{RESULTS}

\section{Sociodemographic characteristics}

A total of 163 people took part in the study with 73 participants in overweight/obese group and 90 participants in the control group (table 1). Mean BMI among overweight/obese people was equal to $31.81 \pm 2.97 \mathrm{~kg} / \mathrm{m}^{2}$, while the mean for controls was $20.70 \pm 2.40 \mathrm{~kg} / \mathrm{m}^{2}$. The mean age of the whole group was $41.47 \pm 13.07$ years old with $58.02 \%$ of women and $41.98 \%$ of men. The mean age of the overweight/obese group was $45.39 \pm 12.08$ years, while it was $38.33 \pm 13.05$ years in controls. Additionally, proportion of males was significantly smaller $(\mathrm{p}<0.05)$ in overweight/obese group (35.29\%) than in controls $(64.71 \%)$. From the ethnicity perspective, there were in total 93 Kazakhs $(57.41 \%)$ and 69 Russians $(42.59 \%)$, who participated in the study. Next, smoking habits varied among study groups with higher proportion of smokers being in controls (34.44\%) than in overweight/obese participants (19.44\%). Finally, SNP frequencies varied significantly among overweight/obese and controls in all gene polymorphisms except those in rs1205 and rs1801133. 
Table 1 Sociodemographic characteristics and frequency of studied single nucleotide polymorphisms genotypes

\begin{tabular}{|c|c|c|c|c|}
\hline & Total & Overweight/obese & Control & $P$ value \\
\hline Total & 163 & 73 & 90 & \\
\hline Mean age $\pm S D$, years & $41.47 \pm 13.07$ & $45.39 \pm 12.08$ & $38.33 \pm 13.05$ & $0.005^{\star}$ \\
\hline Female & $94(58.0 \%)$ & $48(51.0 \%)$ & $46(49.0 \%)$ & $0.046^{\star}$ \\
\hline Male & $68(42.0 \%)$ & $24(35.0 \%)$ & $44(65.0 \%)$ & \\
\hline \multicolumn{5}{|l|}{ Ethnicity, number (\%) } \\
\hline Kazakh & $93(57.0 \%)$ & $33(35.5 \%)$ & $60(64.5 \%)$ & $0.008^{\star}$ \\
\hline Russian & $69(43.0 \%)$ & $39(56.5 \%)$ & $30(43.5 \%)$ & \\
\hline \multicolumn{5}{|l|}{ Smoking, number (\%) } \\
\hline No & $117(72.2 \%)$ & $58(49.6 \%)$ & $59(50.4 \%)$ & $0.034^{*}$ \\
\hline
\end{tabular}

Age and $\mathrm{BMI}$ are presented with mean $\pm \mathrm{SD}$. Rest of the variables are given with number and percentage (\%). Age and BMI $\mathrm{p}$ values were obtained from Student's t-test with unequal variances. Other variables $\mathrm{p}$ values were acquired from the $\chi^{2}$ test.

*Statistically significant $p$ values $(<0.05)$.

BMI, body mass index.

\section{Genes and SNP analysed in the study}

In all, 18 genes and 19 SNPs were analysed in this study (table 2). They were categorised into four physiological subgroups relevant to cardiovascular health, namely inflammation, homocysteine and transsulfuration, blood pressure regulation and vascular endothelial health. These genes were selected due to previous reports suggesting their role in overweight/obesity or metabolic syndrome. Some of them include CRP (rs1205), MTHFR (rs1801133)obesity in children or adults, AGTR1 (rs5186), CBS (rs234706), MTHFR (rs1801131, rs1801133)-metabolic syndrome. ${ }^{21-27}$ SNP in FUT2 gene (rs602662) revealed increased effect on BMI of German cohort of participants. ${ }^{28}$ The full list of tested genes and SNPs is summarised in table 2.

\section{Association of SNPs with overweight/obesity in Kazakhstani population}

Among the 19 SNPs studied, 8 of them showed statistically significant differences between experimental and control groups. These are presented in table 3A,B. Particularly, genotypes under the category inflammation (rs1205), homocysteine and trans-sulphuration (rs1801131, rs1801133, rs234706, rs602662), blood pressure regulation (rs5186) and vascular endothelial health (rs1799889) SNPs. These SNPs had decreased odds of having overweight/obesity. Most of the significant genotypes were heterozygotes except GG in rs602662. Furthermore, allelic analysis for risk of being overweight/obese revealed a statistical difference only in rs1799889. The $\mathrm{G}$ allele decreased odds of overweight/obesity by 0.54 times $(95 \%$ CI 0.34 to 0.84) compared with A allele carriers. None of the tested potential confounders, age, sex, smoking status and ethnicity, were revealed to have any statistical significance in the logistic regression model.

\section{Association of SNPs with overweight/obesity in Kazakhs and Russians}

Analysis of genotype and allelic effect on the risk of obesity/overweight in Kazakhs and Russians separately revealed the following results (table 4). After stratification, rs1205, rs1801131 and rs1801133 lost their statistical significance in Kazakhs and Russians. Meanwhile, two SNPs, rs234706 and rs602662, were still statistically significant in both ethnic groups. AG genotype in rs234706 had a similar effect on overweight/obesity risk among Russians and Kazakhs, namely ORs were equal to 0.128 (95\% CI 0.02 to 0.78 ) and 0.197 (95\% CI 0.05 to 0.78 ), respectively. Furthermore, $\mathrm{G}$ allele in rs602662 decreased the probability of being overweight/obese by $58 \%$ in Kazakhs $(95 \%$ CI 0.22 to 0.80 ) and by $50 \%$ in Russians (95\% CI 0.05 to 0.78 ). Effect on either one of two ethnicities was found in rs5186 (Kazakhs), rs1799889 (Russians) and rs1800871 (Kazakhs). Genotype AC in rs5186 decreased the risk of obesity and overweight by 0.26 times (95\% CI 0.09 to 0.78 ) when compared with AA genotype carriers, while AG genotype in rs1800871 lowered it by $70 \%$ (95\% CI 0.09 to 0.93 ) compared with the reference (AA) group. Meanwhile, analysis of rs1799889 revealed statistical significance of two genotypes in Russians, AG and GG. Individuals with the former genotype had 0.27 -fold (95\% CI 0.07 to 0.97 ) decreased risk of being obese and overweight than AA carriers, while OR value in those with the latter genotype was smaller, 0.21 (95\% CI 0.05 to 0.91 ). Analysis of frequency distribution of genotypes alleles in two ethnicities revealed statistical difference 
Table 2 Summary of single nucleotide polymorphisms tested for association with obesity and overweight, their physiological subgroup, genes they belong to and their rs numbers

\begin{tabular}{|c|c|c|}
\hline $\begin{array}{l}\text { Genes and physiological } \\
\text { subgroup }\end{array}$ & $\begin{array}{l}\text { Gene } \\
\text { symbol }\end{array}$ & Rs number \\
\hline \multicolumn{3}{|l|}{ Inflammation } \\
\hline $\mathrm{C}$ reactive protein & $C R P$ & rs1205 \\
\hline Interleukin-10 & $I L-10$ & rs1800871 \\
\hline \multicolumn{3}{|l|}{ Homocysteine/trans-sulphuration } \\
\hline $\begin{array}{l}\text { Methylenetetrahyrofolate } \\
\text { reductase }\end{array}$ & MTHFR & rs1801133 \\
\hline $\begin{array}{l}\text { Methylenetetrahyrofolate } \\
\text { reductase }\end{array}$ & MTHFR & rs1801131 \\
\hline Cystathionine- $\beta$-synthase & CBS & rs234706 \\
\hline Methionine synthase & MS & rs1805087 \\
\hline Methionine synthase reductase & $M S R$ & rs1801394 \\
\hline Catechol-O-methyltransferase & COMT & rs4680 \\
\hline $\begin{array}{l}\text { Betaine homocysteine } \\
\text { methyltransferase }\end{array}$ & BHMT & rs3733890 \\
\hline Fucosyltransferase 2 & FUT2 & rs602662 \\
\hline Transcobalamine II & TCN2 & rs1801198 \\
\hline \multicolumn{3}{|l|}{ Blood pressure regulation } \\
\hline Angiotensinogen & AGT & rs699 \\
\hline ACE & $A C E$ & rs4340 \\
\hline Angiotensin II receptor-1 & AGTR1 & rs5186 \\
\hline \multicolumn{3}{|l|}{ Vascular endothelial health } \\
\hline $\begin{array}{l}\text { Endothelial nitric oxide } \\
\text { synthase }\end{array}$ & NOS & rs1799983 \\
\hline NADP-oxidase p22 phox & CYBA & rs4673 \\
\hline $\begin{array}{l}\text { NADPH-oxidase-encoded by } \\
\text { CYBA }\end{array}$ & CYBA & rs9932581 \\
\hline $\begin{array}{l}\text { Plasminogen activator } \\
\text { inhibitor-1 }\end{array}$ & PAl-1 & rs1799889 \\
\hline Adiponectin & $A D I P O Q$ & rs1501299 \\
\hline
\end{tabular}

in rs1205 (both), rs5186 (allele), rs234706 (both), rs602662 (allele) and rs1800871 (both).

\section{Haplotype analysis of rs1801131 and rs1801133 found on} MTHFR gene and overweight/obesity

Table 5 depicts haplotype analysis of rs1801131 and rs1801133 located on the MTHFR gene. Combination of $\mathrm{T}$ on rs1801131 and $\mathrm{G}$ rs1801133 had a 0.27 -times $(95 \%$ CI $0.11-0.70, \mathrm{p}$ value, 0.007$)$ protective effect against obesity and overweight than the reference $\mathrm{G}$ and $\mathrm{A}$ alleles on respective SNPs.

\section{DISCUSSION}

Findings from this study suggested that SNPs which are known for their role in cardiovascular health are also associated with risk of overweight/obesity as observed in a Kazakhstani population. Particularly, those SNPs belonging to genes in the homocysteine/transsulphuration pathway. All of the SNPs frequencies were statistically different when compared between controls and overweight/obese people except rs 1205 of the CRP gene and rs1801133 of the MTHFR gene. Further logistic regression analysis of association of genetic polymorphisms with overweight/obesity showed that heterozygotes had decreased risk for OO including rs1205 in CRP, rs5186 in AGTR1, rs234706 in CBS, rs1800871 in interleukin 10 (IL-10), and both rs1801131 and rs1801133 in MTHFR. Meanwhile, homozygote GG in rs602662 in FUT2 and both homozygote GG and heterozygote in rs1799889 of the PAI-1 gene, were shown to be protective against OO. Moreover, after adjusting for age, sex and ethnicity, all SNPs retained their statistical significance except for rs1205, rs1800871 and rs1801133. In contrast, adjustment resulted in a new statistical significance for the G allele in SNP rs602662 of the FUT2 gene. Furthermore, when stratification analysis for ethnicity was carried out it showed that certain SNPs can have statistical significance on the risk of OO in Kazakhs only (rs5186, rs1800871), in Russians only (rs1799889) and in both ethnic groups (rs234706 and rs602662). Finally, haplotype analysis of MTHFR gene polymorphisms revealed a novel finding on having $\mathrm{T}$ allele in rs1801131 and $\mathrm{G}$ in rs1801133 can protect their carriers from OO.

FUT2 protein is crucial for synthesis of $\mathrm{H}$ antigen that is needed for the A and $\mathrm{B}$ antigens production pathway. FUT2 has been found to have a role in the composition of gut microbiota, which, in turn, can affect the risk of obesity due to inadequate interaction between microbes and human organism. ${ }^{2-31}$ This supports our finding that there is a protective association of homozygotes (GG), which is also known as 5G/5G genotype, against $\mathrm{OO}$ providing sufficient representation of $\mathrm{H}$ antigens in gut epithelium. The recent study in German and Danish populations also revealed that $\mathrm{G}$ allele had a positive association with BMI, though our study's analysis did not show any statistical significance for the $\mathrm{G}$ allele. ${ }^{28}$

Though the exact role of PAI-1 in obesity is still unclear, numerous studies show that adipose tissue produces higher amounts of PAI-1 in obese people than in controls, while knockdown of PAI-1 in mice resulted in fat loss; suggesting a role of PAI-1 in fat mass control. ${ }^{32-36}$ Research in Scandinavian countries found a statistically significant difference in the distribution of heterozygote (AG) among obese and control patients, which supports the results of this study. ${ }^{37}$ Moreover, AG and AA genotypes are associated with increased obesity in Turkish population, which shares a common ancestry with Kazakhs. ${ }^{38}$ Association from a different perspective was shown in Mexican study, which revealed increased risk for OO for patients with haplogenotype of several SNPs, namely rs1799889 (G)+rs2227631 (A) + rs757716 (C) ${ }^{39}$ However, Argentinean researchers did not find a statistically significant association of this SNP with obesity. ${ }^{40}$ Additionally, study in Mexico did not find any significant 
Table 3A List of SNPs, genotypes and frequency

\begin{tabular}{|c|c|c|c|c|}
\hline SNP (gene) & Total (\%) & Overweight/obese (\%) & Control (\%) & $P$ value \\
\hline \multicolumn{5}{|l|}{ rs1205 (CRP) } \\
\hline $\mathrm{CC}$ & $60(37.2)$ & 32 (53.3) & $28(46.7)$ & 0.091 \\
\hline Tा & $22(13.7)$ & $11(50.0)$ & $11(50.0)$ & \\
\hline \multicolumn{5}{|c|}{ rs5186 (AGTR1) } \\
\hline $\mathrm{CC}$ & $6(3.7)$ & 5 (83.3) & $1(16.7)$ & \\
\hline \multicolumn{5}{|c|}{ rs234706 (CBS) } \\
\hline AA & $22(13.8)$ & $17(77.3)$ & $5(22.7)$ & $0.000^{*}$ \\
\hline$A G$ & $109(68.1)$ & $35(32.1)$ & $74(67.9)$ & \\
\hline$A G$ & $66(41.0)$ & $35(53.0)$ & $31(47.0)$ & \\
\hline GG & $66(41.0)$ & $18(27.3)$ & $48(72.7)$ & \\
\hline \multicolumn{5}{|c|}{ rs1799889 (PAl-1) } \\
\hline AA & $40(24.8)$ & $25(62.5)$ & $15(37.5)$ & $0.015^{\star}$ \\
\hline$A G$ & $85(52.8)$ & $35(41.2)$ & $50(58.8)$ & \\
\hline GG & $36(22.4)$ & $11(30.6)$ & $25(69.4)$ & \\
\hline \multicolumn{5}{|c|}{ rs1800871 (IL-10) } \\
\hline AA & $27(17.2)$ & $16(59.3)$ & $11(40.7)$ & $0.041^{*}$ \\
\hline$A G$ & $69(43.9)$ & $23(33.3)$ & $46(66.7)$ & \\
\hline AA & $14(8.7)$ & $9(64.3)$ & $5(35.7)$ & 0.079 \\
\hline$A G$ & $61(37.9)$ & $21(34.4)$ & $40(65.6)$ & \\
\hline GG & $86(53.4)$ & $41(47.7)$ & $45(52.3)$ & \\
\hline
\end{tabular}

$0.000^{*}$ indicates $p$ value less than 0.0005 .

*Statistically significant $p$ values $(<0.05)$.

SNP, single nucleotide polymorphism.

Table 3B The genotype and allele associations with overweight/obesity

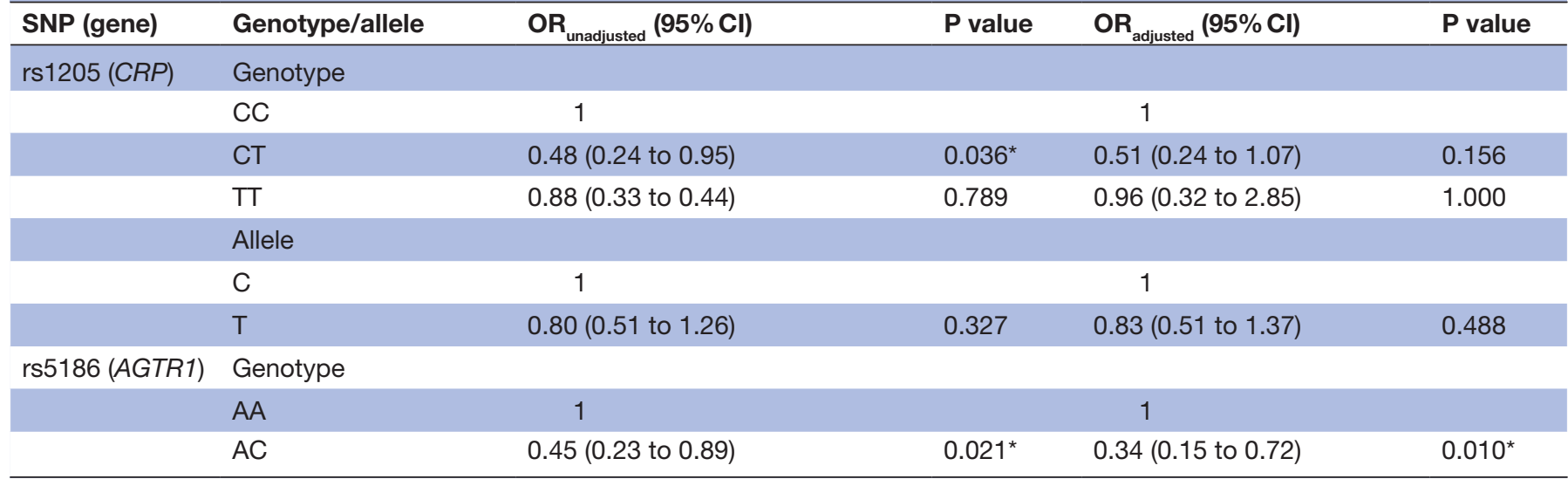




\begin{tabular}{|c|c|c|c|c|c|}
\hline SNP (gene) & Genotype/allele & $\mathrm{OR}_{\text {unadjusted }}(95 \% \mathrm{Cl})$ & $P$ value & $\mathrm{OR}_{\text {adjusted }}(95 \% \mathrm{Cl})$ & $P$ value \\
\hline & $\mathrm{CC}$ & 4.99 (0.56 to 44.44$)$ & 0.149 & 4.59 (0.41 to 51.35$)$ & 0.430 \\
\hline & Allele & & & & \\
\hline & A & 1 & & 1 & \\
\hline & C & 0.79 (0.47 to 1.35$)$ & 0.393 & 0.64 (0.36 to 1.14$)$ & 0.134 \\
\hline \multirow[t]{7}{*}{ rs234706 (CBS) } & Genotype & & & & \\
\hline & $\mathrm{AA}$ & 1 & & 1 & \\
\hline & $A G$ & 0.14 (0.05 to 0.41$)$ & $0.000^{*}$ & 0.21 (0.06 to 0.66$)$ & $0.016^{*}$ \\
\hline & GG & $0.56(0.16$ to 1.96$)$ & 0.364 & 1.31 (0.32 to 5.39$)$ & 1.000 \\
\hline & Allele & & & & \\
\hline & $A$ & 1 & & 1 & \\
\hline & $\mathrm{G}$ & 0.95 (0.61 to 1.47$)$ & 0.803 & 1.20 (0.74 to 1.94$)$ & 0.454 \\
\hline \multirow[t]{7}{*}{ rs602662 (FUT2) } & Genotype & & & & \\
\hline & AA & 1 & & 1 & \\
\hline & $A G$ & 0.69 (0.28 to 1.68$)$ & 0.415 & 0.73 (0.28 to 1.89$)$ & 1.000 \\
\hline & GG & 0.23 (0.09 to 0.58$)$ & $0.002^{*}$ & 0.26 (0.09 to 0.71$)$ & $0.018^{*}$ \\
\hline & Allele & & & & \\
\hline & A & 1 & & 1 & \\
\hline & G & 0.93 (0.53 to 1.63$)$ & 0.796 & 0.45 (0.27 to 0.74$)$ & $0.002^{*}$ \\
\hline \multirow{7}{*}{$\begin{array}{l}\text { rs1799889 (PAl- } \\
\text { 1) }\end{array}$} & Genotype & & & & \\
\hline & AA & 1 & & 1 & \\
\hline & $A G$ & 0.42 (0.19 to 0.91$)$ & $0.028^{*}$ & 0.44 (0.19 to 1.01$)$ & 0.112 \\
\hline & GG & 0.26 (0.10 to 0.69$)$ & $0.006^{*}$ & 0.23 (0.08 to 0.66$)$ & $0.012^{*}$ \\
\hline & Allele & & & & \\
\hline & $A$ & 1 & & 1 & \\
\hline & G & 0.54 (0.34 to 0.84$)$ & $0.006^{*}$ & 0.51 (0.31 to 0.83 ) & $0.007^{*}$ \\
\hline \multirow{7}{*}{$\begin{array}{l}\text { rs1800871 (IL- } \\
\text { 10) }\end{array}$} & Genotype & & & & \\
\hline & AA & 1 & & 1 & \\
\hline & $A G$ & 0.34 (0.14 to 0.86 ) & $0.022^{*}$ & 0.34 (0.12 to 0.94$)$ & 0.076 \\
\hline & GG & 0.67 (0.27 to 1.66$)$ & 0.384 & 0.66 (0.24 to 1.85$)$ & 0.876 \\
\hline & Allele & & & & \\
\hline & A & 1 & & 1 & \\
\hline & $\mathrm{G}$ & 0.95 (0.60 to 1.50$)$ & 0.826 & 0.95 (0.58 to 1.57$)$ & 0.860 \\
\hline \multirow{7}{*}{$\begin{array}{l}\text { rs1801131 } \\
\text { (MTHFR) }\end{array}$} & Genotype & & & & \\
\hline & GG & 1 & & 1 & \\
\hline & GT & 0.27 (0.09 to 0.75$)$ & $0.012^{*}$ & 0.26 (0.08 to 0.79$)$ & $0.034^{*}$ \\
\hline & $T T$ & $0.52(0.19$ to 1.41$)$ & 0.200 & 0.50 (0.17 to 1.45$)$ & 0.408 \\
\hline & Allele & & & & \\
\hline & G & 1 & & 1 & \\
\hline & $\mathrm{T}$ & 0.93 (0.58 to 1.47$)$ & 0.741 & 0.91 (0.55 to 1.49$)$ & 0.715 \\
\hline \multirow{4}{*}{$\begin{array}{l}\text { rs1801133 } \\
\text { (MTHFR) }\end{array}$} & Genotype & & & & \\
\hline & AA & 1 & & 1 & \\
\hline & $A G$ & 0.29 (0.09 to 0.98$)$ & $0.047^{*}$ & 0.29 (0.08 to 1.10$)$ & 0.070 \\
\hline & GG & 0.51 (0.16 to 1.63$)$ & 0.255 & 0.66 (0.18 to 2.36$)$ & 0.533 \\
\hline
\end{tabular}




\begin{tabular}{|c|c|c|c|c|c|}
\hline SNP (gene) & Genotype/allele & $\mathrm{OR}_{\text {unadjusted }}(95 \% \mathrm{Cl})$ & $P$ value & OR $_{\text {adjusted }}(95 \% \mathrm{Cl})$ & $P$ value \\
\hline & \multicolumn{5}{|l|}{ Allele } \\
\hline & $\mathrm{G}$ & 1.02 (0.62 to 1.66$)$ & 0.060 & 1.21 (0.71 to 2.06$)$ & 0.469 \\
\hline
\end{tabular}

*Statistically significant $p$ values $(<0.05)$.

SNP, single nucleotide polymorphism.

results in terms of PAI-1 SNP rs1799889 and the risk of being obese. ${ }^{41}$

IL-10 is an important anti-inflammatory cytokine, and low levels of IL-10 are associated with obesity, and thus leading to impaired immune system and other consequences including cardiovascular diseases. ${ }^{42}{ }^{43}$ In our study AA genotype in rs1800871 of IL-10 had the highest risk of getting obese in Kazakhs only. Meanwhile, research of Indian patients with metabolic syndrome and high BMI, showed increased risk of obesity for the A allele carriers, though our study did not find statistical difference for this allele. ${ }^{44}$ We hypothesise that patients with the AA genotype could have the lowest levels of IL-10, and hence the increased risk of being $\mathrm{OO}$.

MTHFR participates in the methionine to cysteine conversion process, and it is believed that rs1801131 and rs1801133 polymorphisms can cause overexpression of leptin gene, and thus leading to growth of adipose tissue. ${ }^{45}$ In this study, the GT genotype in SNP rs1801133 of MTHFR showed protective features against overweight/ obesity. Meanwhile, similar research using logistic regression revealed positive results only in study of Chinese patients with type 2 diabetes and AA genotype. ${ }^{46}$ In contrast, studies in Lithuania, China, Italy and Ecuador, which also used logistic regression, did not find any statistically significant link between this SNP and overweight/ obesity. ${ }^{45-49}$ In the studies among Chinese children, A allele was found to have association with obesity, though in our study it did not reach significance possibly due to smaller sample size. ${ }^{22} 27$

SNP rs1801131 on the same gene, MTHFR, has been studied less extensively, positive association of this SNP from our research was not supported by studies carried out on Chinese, Ecuadorian and European populations. ${ }^{4-50}$ However, results from an Italian research, that studied both rs1801131 and rs1801133, found increased risk for carriers with the AC genotype in rs1801131 for having an overweight/obesity trait. ${ }^{45}$ As discussed earlier, GT genotype was also implied to play a role in metabolic syndrome (hypertension) among Chinese elderly. ${ }^{26}$ However, this finding was not observed in the longitudinal study and in our study.

In this study CBS SNP rs234706's is found to have a significant association with obesity, CBS like MTHFR, also participates in the pathway of conversion of methionine to cysteine, was not confirmed to be significantly associated with obesity by neither the large European study in nine countries (Germany, Spain, Italy, Hungary, Austria,
Sweden, France, Greece and the UK) nor the study carried out in India. ${ }^{51}$ In the GWAS study A allele of rs234706 was found to have significant dysregulation of CBS, suggesting its role in impaired lipid metabolism. ${ }^{25}$ Though in our study A allele did not reach statistical significance, only AG genotype. Furthermore, there is insufficient number of studies on humans to elucidate the role of CBS in obesity risk. However, the study in rodents suggested a role for CBS in cardiac lipotoxicity, in which deficiency of at least one CBS gene (CBS +/-) was associated with increased fatty acid uptake, heart weight and fasting insulin levels compared with the wild type mice $(\mathrm{CBS}+/+){ }^{52}$

The decreased risk for OO that we obtained for CRP SNP rs1205, however, is not supported by studies in Brazilians and Mexican-Americans. ${ }^{53}$ CRP is an important inflammatory marker, often induced by adipose tissue via proinflammatory cytokines (Tumour Necrosis Factor $-\alpha$, IL-6) ${ }^{55}{ }^{56}$ It has been reported to be associated with various cardiovascular diseases such as myocardial infarction, stroke, peripheral vascular disease.$^{57}$ Also, elevated CRP levels have been linked with increased risk of obesity ${ }^{55-59}$ In the Brazilian study of children and adolescents $\mathrm{T}$ allele had increased odds for hypercholesterolaemia, although in our study it did not get statistical significance.$^{21}$ Furthermore, it was found that CC genotype in rs1205 of CRP results in high levels of the corresponding protein in Taiwanese, and our study provides possible additional evidence for this association. ${ }^{60}$

AGTR1 protein takes part in blood pressure regulation, namely the renin angiotensin system. Though there is limited information on the exact pathway in which it participate in promoting obesity, there are several speculations regarding its role, including the expression of AGTR1 in adipose tissue, its participation in the production of various proteins and molecules by adipocytes (prostacyclin, norepinephrine, nitric oxide). ${ }^{61-63}$ As a result, mature adipocytes release cytokines, which lead to inflammation, vessel damage, hypertension. ${ }^{64}$ These studies provide support and explanation for the association of rs1205 in AGTR1 and OO found in our study. However, while our results show that carriers with AC in AGTR1 SNP rs5186 had protective effect against OO, in Romanian population carriers with either AC or CC genotype had the opposite effect, particularly it was associated with an increased risk of obesity. ${ }^{65}$ However, Egyptian and Tunisian studies revealed no statistically significant results. ${ }^{667}$ 


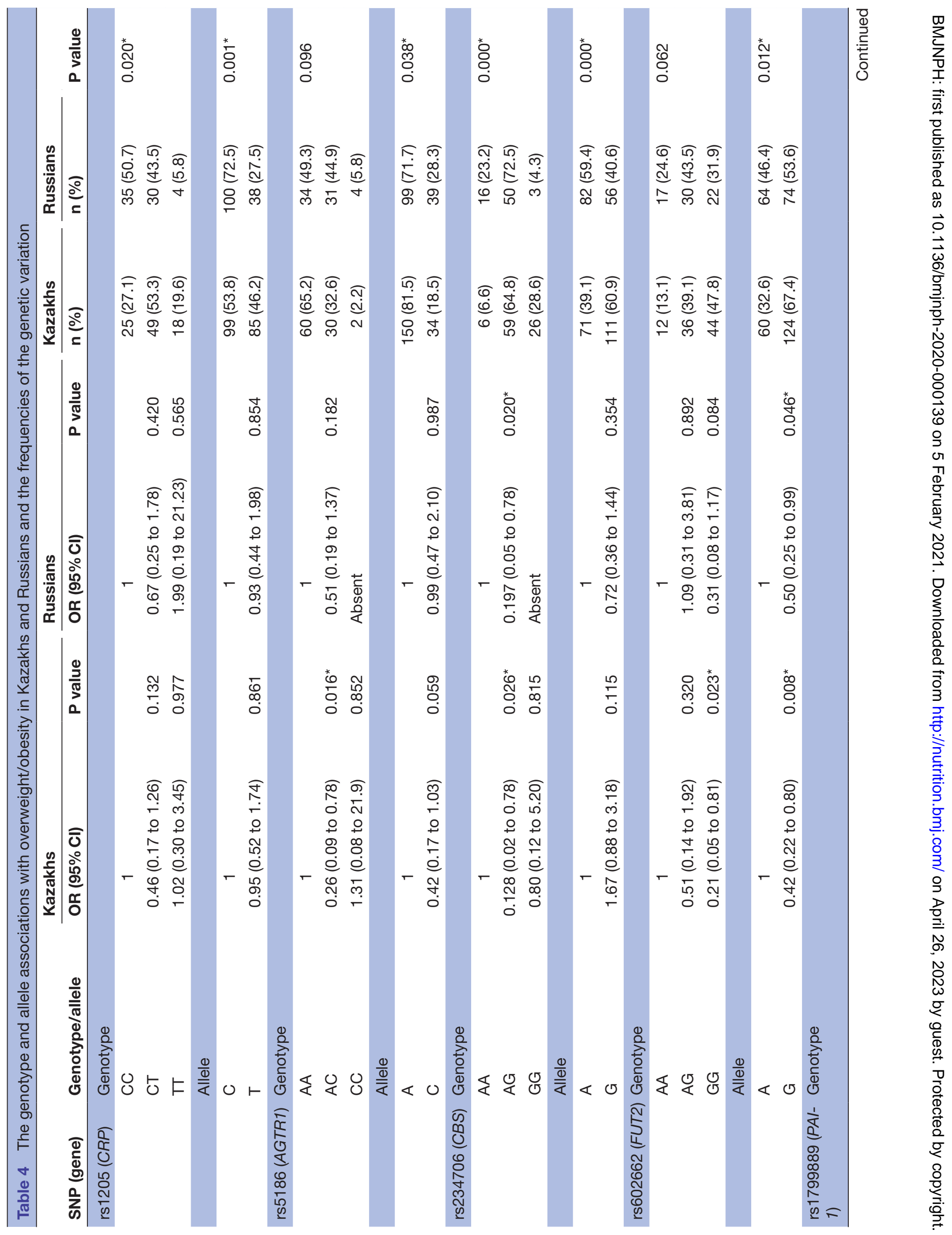




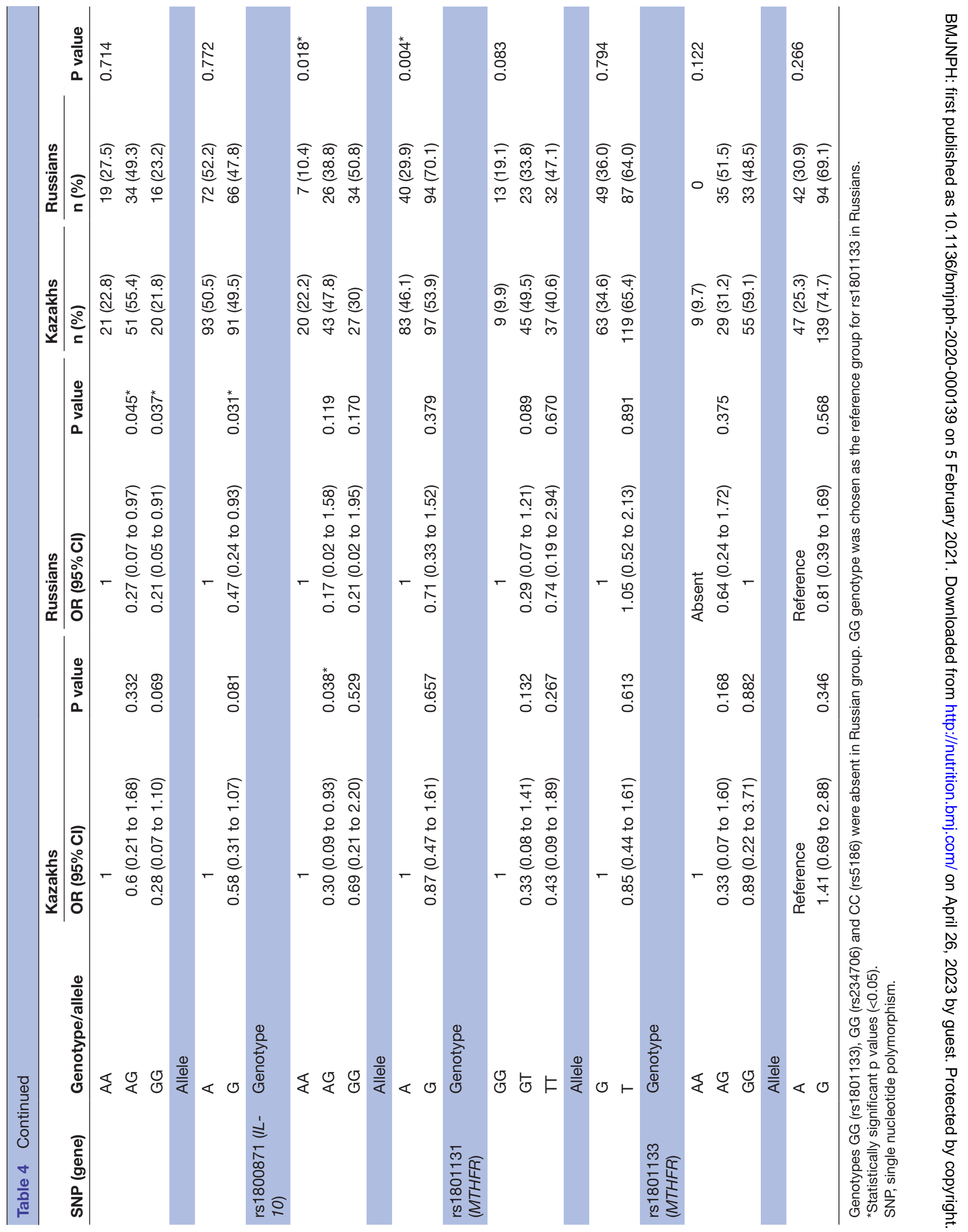


Table 5 Haplotype analysis of rs 1801131 and rs1801133 found on MTHFR gene with association with overweight/obesity

\begin{tabular}{lllllll}
\hline & Rs1801131 & Rs1801133 & Overweight/obese, $\mathbf{n}(\%)$ & Control, $\mathbf{n}$ (\%) & OR (95\% Cl) & P value \\
\hline Haplotype 1 & G & A & $8(26.7)$ & $22(73.3)$ & Reference & \\
Haplotype 2 & T & G & $46(38.7)$ & $73(61.3)$ & $0.27(0.11$ to 0.70) & $0.007^{\star}$ \\
\hline
\end{tabular}

*Statistically significant $p$ values $(<0.05)$.

Though statistically significant differences in both allele and genotype distribution among Kazakh and Russians were found in CRP, CBS and IL-10 gene polymorphisms, stratification analysis revealed ethnic-specific associations regarding their risk for OO. In particular, rs234706 (CBS) should be considered a potential risk factor for $\mathrm{OO}$ in both ethnicities, while rs1800871 (IL-10) is statistically significant for Kazakhs but not for Russians.

Our analysis indicated that carriers of $\mathrm{T}$ in $\mathrm{rs} 1801131$ and $G$ in rs1801133 in MTHFR had decreased OR for being OO. And this is an important novel finding as no research reports studying the influence of rs1801131 and rs1801133 haplotype on obesity risk was found up to February 2019. However, there are a number of studies showing the association of just MTHFR rs1801133, C677T with obesity. It will be interesting and important for further studies with bigger sample size to confirm the association of the MTHFR haplotype to OO in future.

This study has several major limitations. First, the total number of participants studied is small $(\mathrm{n}=163)$, and they were predominantly from one region of Kazakhstan, Kostanay city. Therefore, other regions remain underrepresented. Second, there is a lack of measured clinical parameters such as blood pressure, waist and hip circumference, and other comorbidities including hypertension, metabolic syndrome. Third, the lack of similar studies from the Central Asian regions do not allow proper comparison of these new findings. Therefore, further research in these populations would be useful for elucidating the role of these SNPs and the risk of overweight/ obesity. Finally, multiple SNPs interaction, which might also influence risk of $\mathrm{OO}$, was not analysed in this study and this will be a useful step in our future research.

\section{CONCLUSIONS}

This study found associations of SNPs involved in cardiovascular health with overweight/obesity trait in Kazakhstani population. Genetic polymorphisms from the two major ethnicities, Kazakhs and Russians, were analysed, and associations in one or both were found. These findings will be helpful in predicting genetic risk for overweight/obesity and provide further understanding and guide treatment strategies for this condition in the country.

Acknowledgements Genotyping analyses were performed with the assistance of Fitgenes Pte, Australia.

Contributors Conceptualisation: C-KC and AA. Formal analysis, sample and data curation: MR, Al, RC, DY, UK, AA. Statistical analysis: Al, MR, C-KC, RC. Writing- original draft preparation: MR, C-KC, M-YC. Writing—review and editing: C-KC, MR, $M-Y C, A A$.

Funding This work was supported by the Ministry of Education and Science of the Republic of Kazakhstan (Grants No. AP05134683, AP05134737, BR05236508).

Competing interests C-KC has minimal shares in Fitgenes Pte. Fitgenes Pte had no role in the design of the study; in the collection, analyses or interpretation of data; in the writing of the manuscript or in the decision to publish the results. C-KC and $\mathrm{RC}$ are related as father and son.

Patient consent for publication Not required.

Ethics approval All protocols for the study were approved by the Ethics Committee of Center for Life Sciences, National Laboratory Astana, Nazarbayev University, Kazakhstan (Protocol IREC \#20, 22 September 2017). CLS IRB number registered at OHRP site is IRB00008333 (https://ohrp.cit.nih.gov/search//rbDtl.aspx).

Provenance and peer review Not commissioned; externally peer reviewed by Dr Shao-Qing Wen, Fudan University Institute of Archaeological Science and Dr Emmanuel Baah, University of North Carolina System, Nutrition Research Institute.

Data availability statement All data relevant to the study are included in the article or uploaded as supplementary information. Deidentified participant data are stored with National Lab Astana.

Open access This is an open access article distributed in accordance with the Creative Commons Attribution Non Commercial (CC BY-NC 4.0) license, which permits others to distribute, remix, adapt, build upon this work non-commercially, and license their derivative works on different terms, provided the original work is properly cited, appropriate credit is given, any changes made indicated, and the use is non-commercial. See: http://creativecommons.org/licenses/by-nc/4.0/.

\section{ORCID iDs}

Alpamys Issanov http://orcid.org/0000-0002-8968-2655

Mei-Yen Chan http://orcid.org/0000-0003-2324-9338

\section{REFERENCES}

1 World Health Organization. Media centre obesity and overweight. Available: http://www.who.int/mediacentre/factsheets/fs311/en/ [Accessed 5 Jan 2018].

2 World Health Organization. Kazakhstan. Available: http://www.euro. who.int/_data/assets/pdf_file/0019/243307/Kazakhstan-WHOCountry-Profile.pdf?ua=1 [Accessed 5 Jan 2018].

3 World Health Organization. Non-Communicable diseases country profiles. Available: http://www.who.int/nmh/countries/kaz_en.pdf/ [Accessed 1 May 2018].

4 Statistics Committee of the Ministry of national economy of Kazakhstan. Available: http://stat.gov.kz/faces/wcnav externalld/ publBullS14-2016?lang=ru\&_afrLoop $=5672968181701525 \# \% 40 \%$ 3F_afrLoop\%3D5672968181701525\%26lang\%3Dru\%26_adf.ctrlstate\%3Dnrpydd5st_4/ [Accessed 6 Jan 2018].

5 Hruby A, Hu FB. The epidemiology of obesity: a big picture. Pharmacoeconomics 2015;33:673-89.

6 Herrera BM, Lindgren CM. The genetics of obesity. Curr Diab Rep 2010;10:498-505.

7 Dina C, Meyre D, Gallina S, et al. Variation in FTO contributes to childhood obesity and severe adult obesity. Nat Genet 2007;39:724-6.

8 Xi B, Shen Y, Zhang M, et al. The common rs9939609 variant of the fat mass and obesity-associated gene is associated with obesity risk in children and adolescents of Beijing, China. BMC Med Genet 2010;11:107.

9 Hassanein MT, Lyon HN, Nguyen TT, et al. Fine mapping of the association with obesity at the FTO locus in African-derived populations. Hum Mol Genet 2010;19:2907-16. 
10 Wing MR, Ziegler J, Langefeld CD, et al. Analysis of FTO gene variants with measures of obesity and glucose homeostasis in the IRAS family study. Hum Genet 2009;125:615-26.

11 Prakash J, Mittal B, Srivastava A, et al. Association of FTO rs9939609 SNP with obesity and obesity- associated phenotypes in a North Indian population. Oman Med J 2016;31:99-106.

12 Zhang X-H, Zhang M, He J, et al. Comparison of anthropometric and atherogenic indices as screening tools of metabolic syndrome in the Kazakh adult population in Xinjiang. Int J Environ Res Public Health 2016;13:428

$13 \mathrm{Gu} \mathrm{D,} \mathrm{Reynolds} \mathrm{K,} \mathrm{Wu} \mathrm{X,} \mathrm{et} \mathrm{al.} \mathrm{Prevalence} \mathrm{of} \mathrm{the} \mathrm{metabolic} \mathrm{syndrome}$ and overweight among adults in China. Lancet 2005;365:1398-405.

$14 \mathrm{Hu}$ YH, Liu JM, Zhang M, et al. Association between polymorphisms of fat mass and obesity-associated gene and metabolic syndrome in Kazakh adults of Xinjiang, China. Genet Mol Res 2015;14:14597-606.

15 Baturin AK, Sorokina El, Pogozheva AV, et al. [Regional features of obesity-associated gene polymorphism (rs9939609 FTO gene and gene Trp64Arg ADRB3) in Russian population]. Vopr Pitan 2014:83:35-41.

16 Rankinen T, Zuberi A, Chagnon YC, et al. The human obesity gene map: the 2005 update. Obesity 2006;14:529-644.

17 Pacanowski MA, Zineh I, Li H, et al. Adrenergic gene polymorphisms and cardiovascular risk in the NHLBI-sponsored women's ischemia syndrome evaluation. J Trans/ Med 2008;6:11.

18 Locke AE, Kahali B, Berndt SI, et al. Genetic studies of body mass index yield new insights for obesity biology. Nature 2015;518:197-206.

19 Davis A, Terlikbayeva A, Aifah A, et al. Risks for tuberculosis in Kazakhstan: implications for prevention. Int J Tuberc Lung Dis 2017;21:86-92.

20 Hermosilla S, You P, Aifah A, et al. Identifying risk factors associated with smear positivity of pulmonary tuberculosis in Kazakhstan. PLoS One 2017;12:e0172942.

21 Todendi PF, Possuelo LG, Klinger El, et al. Low-Grade inflammation markers in children and adolescents: influence of anthropometric characteristics and CRP and IL6 polymorphisms. Cytokine 2016;88:177-83.

22 Fu L, Zhang M, Hu Y-Q, et al. Gene-Gene interactions and associations of six hypertension related single nucleotide polymorphisms with obesity risk in a Chinese children population Gene 2018:679:320-7.

23 Herrera CL, Castillo W, Estrada P, et al. Association of polymorphisms within the renin-angiotensin system with metabolic syndrome in a cohort of Chilean subjects. Arch. Endocrinol. Metab. 2016;60:190-8.

24 Shah VN, Cheema BS, Sharma R, et al. ACAC $\beta$ gene (rs2268388) and AGTR1 gene (rs5186) polymorphism and the risk of nephropathy in Asian Indian patients with type 2 diabetes. Mol Cell Biochem 2013;372:191-8.

25 Sharma A, Gulbahce N, Pevzner SJ, et al. Network-Based analysis of genome wide association data provides novel candidate genes for lipid and lipoprotein traits. Mol Cell Proteomics 2013;12:3398-408.

26 Yang J, Liu J, Liu J, et al. Genetic association study with metabolic syndrome and metabolic-related traits in a cross-sectional sample and a 10-year longitudinal sample of Chinese elderly population. PLoS One 2014;9:e100548.

$27 \mathrm{Xi} \mathrm{B}$, Zhao X, Chandak GR, et al. Influence of obesity on association between genetic variants identified by genome-wide association studies and hypertension risk in Chinese children. Am J Hypertens 2013;26:990-6.

28 Allin $\mathrm{KH}$, Friedrich N, Pietzner M, et al. Genetic determinants of serum vitamin B12 and their relation to body mass index. Eur $J$ Epidemiol 2017;32:125-34.

29 Bäckhed F, Ding H, Wang T, et al. The gut microbiota as an environmental factor that regulates fat storage. Proc Natl Acad Sci U S A 2004:101:15718-23.

30 Turnbaugh PJ, Hamady M, Yatsunenko T, et al. A core gut microbiome in obese and lean twins. Nature 2009;457:480-4.

31 Le Chatelier E, Nielsen T, Qin J, et al. Richness of human gut microbiome correlates with metabolic markers. Nature 2013;500:541-6.

32 Yamamoto K, Saito H. A pathological role of increased expression of plasminogen activator inhibitor- 1 in human or animal disorders [abstract]. Int J H 1998;68:371-85.

33 Juhan-Vague I, Alessi MC, Morange PE. Hypofibrinolysis and increased PAI-1 are linked to atherothrombosis via insulin resistance and obesity. Ann Med 2000;32 Suppl 1:78-84.

34 Bastard JP, Piéroni L, Hainque B. Relationship between plasma plasminogen activator inhibitor 1 and insulin resistance. Diabetes Metab Res Rev 2000;16:192-201.
35 Schäfer K, Fujisawa K, Konstantinides S, et al. Disruption of the plasminogen activator inhibitor 1 gene reduces the adiposity and improves the metabolic profile of genetically obese and diabetic ob/ ob mice. Faseb J 2001;15:1840-2.

36 Esposito K, Pontillo A, Giugliano F, et al. Association of low interleukin-10 levels with the metabolic syndrome in obese women. $J$ Clin Endocrinol Metab 2003;88:1055-8.

37 Hoffstedt J, Andersson I-L, Persson L, et al. The common -675 $4 \mathrm{G} / 5 \mathrm{G}$ polymorphism in the plasminogen activator inhibitor -1 gene is strongly associated with obesity. Diabetologia 2002;45:584-7.

38 Berberoğlu M, Evliyaoğlu $\mathrm{O}$, Adıyaman $\mathrm{P}$, et al. Plasminogen activator inhibitor-1 (PAl-1) gene polymorphism (-675 4G/5G) associated with obesity and vascular risk in children. $J$ Pediatr Endocrinol Metab 2006;19:741-8

39 de la Cruz-Mosso U, Elena Ramos-Arellano L, Francisco MuñozValle $\mathrm{J}$, et al. Pai-1 haplogenotype confers genetic susceptibility for obesity and hypertriglyceridemia in Mexican children. Invest Clin 2016;57:246-58

40 Wingeyer SDP, Graffigna MN, Belli SH, et al. Role of -675 4G/5G in the plasminogen activator inhibitor-1 gene and -308G/A tumor necrosis factor- $\alpha$ gene polymorphisms in obese Argentinean patients. Genet Test Mol Biomarkers 2012:16:372-5.

41 Vashi N, Stryjecki C, Peralta-Romero J, et al. Genetic markers of inflammation may not contribute to metabolic traits in Mexican children. PeerJ 2016;4:e2090.

42 Manigrasso MR, Ferroni P, Santilli F, et al. Association between circulating adiponectin and interleukin-10 levels in android obesity: effects of weight loss. J Clin Endocrinol Metab 2005;90:5876-9.

43 Scarpelli D, Cardellini M, Andreozzi F, et al. Variants of the interleukin-10 promoter gene are associated with obesity and insulin resistance but not type 2 diabetes in Caucasian Italian subjects. Diabetes 2006;55:1529-33.

44 Madeshiya AK, Singh S, Dwivedi S, et al. Association of IL-10 gene $(-1082 A>G,-819 C>T$ and $-592 C>A)$ polymorphism and its serum level with metabolic syndrome of north Indian subjects. $J$ Genet 2017;96:53-64.

45 Terruzzi I, Senesi P, Fermo I, et al. Are genetic variants of the methyl group metabolism enzymes risk factors predisposing to obesity? $J$ Endocrinol Invest 2007;30:747-53.

46 Zhi X, Yang B, Fan S, et al. Additive interaction of MTHFR C677T and MTRR A66G polymorphisms with being Overweight/Obesity on the risk of type 2 diabetes. Int $J$ Environ Res Public Health 2016;13:1243.

47 Kupcinskiene K, Murnikovaite M, Varkalaite G, et al. Thrombosis Related $A B O, F 5, M T H F R$, and FGG Gene Polymorphisms in Morbidly Obese Patients. Dis Markers 2016;2016:1-7.

48 Fan S-J, Yang B-Y, Zhi X-Y, et al. Are MTHFR C677T and MTRR A66G polymorphisms associated with Overweight/Obesity risk? from a case-control to a meta-analysis of 30,327 subjects. Int J Mol Sci 2015;16:11849-63.

49 Chedraui P, Pérez-López FR, Escobar GS, et al. Polymorphisms of the FTO and MTHFR genes and vascular, inflammatory and metabolic marker levels in postmenopausal women. $J$ Endocrinol Invest 2016;39:885-90.

50 Bokor S, Meirhaeghe A, Ruiz JR, et al. Common polymorphisms in six genes of the methyl group metabolism pathway and obesity in European adolescents. Int J Pediatr Obes 2011;6:e336-44.

51 Tabassum R, Jaiswal A, Chauhan G, et al. Genetic variant of AMD1 is associated with obesity in urban Indian children. PLoS One 2012;7:33162.

52 Glier MB, Olson JD, Gerrard SL, et al. Dysfunctional cardiac lipid metabolism in cystathionine-beta-synthase deficient mice with dietinduced weight gain. Can J Cardiol 2013;29:S172.

53 Todendi PF, Klinger El, Ferreira MB, et al. Association of IL-6 and CRP gene polymorphisms with obesity and metabolic disorders in children and adolescents. An Acad Bras Cienc 2015;87:915-24.

54 Duran-Gonzalez J, Ortiz I, Gonzales E, et al. Association study of candidate gene polymorphisms and obesity in a young Mexican-American population from South Texas. Arch Med Res 2011:42:523-31.

55 Yudkin JS, Stehouwer CD, Emeis JJ, et al. C-Reactive protein in healthy subjects: associations with obesity, insulin resistance, and endothelial dysfunction: a potential role for cytokines originating from adipose tissue? Arterioscler Thromb Vasc Biol 1999;19:972-8.

56 Hotamisligil GS, Arner P, Caro JF, et al. Increased adipose tissue expression of tumor necrosis factor-alpha in human obesity and insulin resistance. J Clin Invest 1995:95:2409-15.

57 Ridker PM. High-Sensitivity C-reactive protein: potential adjunct for global risk assessment in the primary prevention of cardiovascular disease. Circulation 2001;103:1813-8. 
58 Ridker PM. Clinical application of C-reactive protein for cardiovascular disease detection and prevention. Circulation 2003;107:363-9.

59 Hak AE, Stehouwer CD, Bots ML, et al. Associations of C-reactive protein with measures of obesity, insulin resistance, and subclinical atherosclerosis in healthy, middle-aged women. Arterioscler Thromb Vasc Biol 1999;19:1986-91.

60 Teng M-S, Hsu L-A, Wu S, et al. Association between C-reactive protein gene haplotypes and C-reactive protein levels in Taiwanese: interaction with obesity. Atherosclerosis 2009;204:e64-9.

61 Darimont C, Vassaux G, Ailhaud G, et al. Differentiation of preadipose cells: paracrine role of prostacyclin upon stimulation of adipose cells by angiotensin-II. Endocrinology 1994;135:2030-6.

62 Engeli S, Negrel R, Sharma AM. Physiology and pathophysiology of the adipose tissue renin-angiotensin system. Hypertension 2000;35:1270-7.
63 English V, Cassis L. Facilitation of sympathetic neurotransmission contributes to angiotensin regulation of body weight. J Neural Transm 1999;106:631-44.

64 Wisse BE. The inflammatory syndrome: the role of adipose tissue cytokines in metabolic disorders linked to obesity. J Am Soc Nephrol 2004;15:2792-800

65 Procopciuc LM, Sitar-Tăut A, Pop D, et al. Renin angiotensin system polymorphisms in patients with metabolic syndrome (Mets). Eur J Intern Med 2010;21:414-8.

66 Abd El-Aziz TA, Mohamed RH, Rezk NA. Association of angiotensin II type I and type II receptor genes polymorphisms with the presence of premature coronary disease and metabolic syndrome. $\mathrm{Mol} \mathrm{Biol}$ Rep 2014;41:1027-33.

67 Mehri S, Mahjoub S, Hammami S, et al. Renin-Angiotensin system polymorphisms in relation to hypertension status and obesity in a Tunisian population. Mol Biol Rep 2012;39:4059-65. 